\title{
Perverse Institutionalism: NATO and the Greco-Turkish Conflict
}

\author{
Ronald R. Krebs
}

Last year the U.S. Senate overwhelmingly approved the expansion of the Atlantic alliance. Whereas some advocates of enlarging NATO, particularly Eastern European leaders for whom the Soviets' iron grip is an all too recent memory, stress the extension of the alliance's traditional deterrent function, others acknowledge that Russia is in no position to reconquer its former empire. Rather, they argue that membership in NATO would stabilize the region by filling the power vacuum and eliminating the need for security competition. Traditionally a volatile area, East-Central Europe is rife with potential irredentist and ethnic conflicts, and NATO can help arbitrate and limit these disputes. ${ }^{1}$ Critics have denounced the move as unnecessarily provocative to Russia, and they have also decried its hefty cost. ${ }^{2}$ But they have not challenged the claim that alliances create zones of peace. ${ }^{3}$

Policymakers have swiftly embraced this intuitively appealing argument. In a 1996 campaign speech, President Bill Clinton trumpeted the virtues of alliance: "Through NATO, Western Europe became a source of stability instead of hostility. France and Germany moved from conflict to cooperation.... I came to office convinced that NATO can do for Europe's East what it did for Europe's West." 4 This logic is attractive, but it overstates the alliance's achievements. The triumph of Franco-German reconciliation must be balanced by the failure to suppress the persistent discord within NATO's southeastern flank. At least once in every decade since World War II, Greece and Turkey have nearly come to blows, and a host of more minor incidents and skirmishes have further marred their relations. Historians have maintained that the

For helpful comments and criticisms on earlier drafts, I am grateful to Tozun Bahcheli, Christopher Ball, Timothy Crawford, Amitabh Dubey, Stacie Goddard, Robert Jervis, Jack Levy, Daniel Nexon, Jack Snyder, Richard Ullman, Fareed Zakaria, participants in the Columbia Security Studies Workshop, two anonymous reviewers, and the editors of International Organization.

1. See Asmus et al. 1993; Asmus et al. 1995; Duffield 1994; and Ball 1998.

2. See Mandelbaum 1996; Brown 1995; and Perlmutter and Carpenter 1998.

3. For two opposing perspectives on NATO enlargement that nonetheless agree on this point, see Art 1998, and Russett and Stam 1998. For an exception, see Carpenter 1994.

4. New York Times, 23 October 1996, A20.

International Organization 53, 2, Spring 1999, pp. 343-377

() 1999 by The IO Foundation and the Massachusetts Institute of Technology 
pair pursued their rivalry despite NATO's best efforts, yet I argue that, although the alliance did not create the divisive issues separating these longtime antagonists, it bears a significant degree of responsibility for the tensions between them.

Alliances can, under certain conditions, intensify conflict among their members. Unlike structural realists, who believe that institutions matter only at the margins of international relations, I contend that alliances are more than mere means of accumulating power. But unlike neoliberal institutionalists, who portray institutions as mitigating the dangers of anarchy and whose reasoning bolsters the Clinton administration's optimistic expectations, I doubt that their impact is always beneficial. In this article I seek to bridge the gap between these two approaches by taking the first steps toward a "realist institutionalism," marrying the belief that institutions matter with a skepticism as to their effects. ${ }^{5}$

I also seek to right a notable bias in the alliance literature, which has generally ignored the possibility of serious conflict among allies. ${ }^{6}$ Over two decades ago Paul Schroeder argued that political scientists'emphasis on the operations of the balance of power had flattened the historical richness of alliance patterns and purposes and that the record demonstrated "that alliances in practice do not always serve to increase a nation's power and security, and that allies often clash with each other more than they unite in common cause." Alliances are "associative-antagonistic relationships": they are as often devices uniting rivals as means of linking friends. ${ }^{7}$

Schroeder's cry has gone largely unheeded over the last twenty years. Realist studies, focused on alliances as balance or bandwagon, have not concentrated on their internal politics. ${ }^{8}$ Scholarship on intra-alliance conflict has explored the problem of burden sharing, not conflicts that strike at the core of the commitment. ${ }^{9}$ Few institutionalists have ventured into security studies, and their insights have spoken more to the persistence of alliance institutions and policies or to how alliances foster cooperation..$^{10}$ Other scholars in traditions ranging from formal theory ${ }^{11}$ to social psychology ${ }^{12}$ have built their analyses on the assumption of mutuality of purpose.

5. In its intellectual tradition, this article complements Schweller and Priess 1997. It also contributes to the effort to move beyond the debate over whether institutions matter and explore variation in institutional effects on state behavior; see Martin and Simmons 1998

6. Exceptions include Bueno de Mesquita 1981; Ray 1990; and Weitsman 1997.

7. Schroeder $1976,256-57$.

8. See Waltz 1979; and Walt 1987. This bias is particularly marked in balance-of-interest theory, in which status quo states align with other satisfied states, and revisionists of all stripes band together; see Schweller 1994

9. The seminal work here is Olson and Zeckhauser 1966. For a challenge to the public-goods thesis, see Kupchan 1988.

10. See Duffield 1995; and Wallander and Keohane 1998.

11. Bueno de Mesquita assumes allies lack conflicting objectives. Bueno de Mesquita 1981. Since each has absolute utility for the other, any change that might affect the other's foreign policy signals a forthcoming deterioration in relations: hence the outcome of war between allies. This explanation is clearly inadequate once one drops the unrealistic assumption that allies possess identical goals. For a similar critique, see Levy 1989, 249, 306. Ray refines the coding and empirical analysis but fails to move theoretically beyond Bueno de Mesquita's explanation. Ray 1990.

12. Mercer assumes allies always find desirable each other's demonstrations of resolve (and that antagonists are necessarily displeased with such behavior), but this assumption cannot be justified unless one 
Even Glenn Snyder, who has shown unusual sensitivity to the political bargains at the heart of alliance, denies the possibility of armed conflict between allies, arguing that alliances generate patterns of amity and enmity, allies support growth in each other's power resources, and within alliance states develop shared interests. ${ }^{13}$ Yet even as allies provide security, they can pose real threats, not just limits to a state's freedom of action. Alliance does not entirely eliminate conflicts of interest and concerns over relative position.

I examine the effects of membership in an institutionalized multilateral alliance on the relations of small powers and offer three core arguments in the realist institutionalist vein. ${ }^{14}$ First, when accession to the alliance brings a security guarantee to small states, it eliminates the primary threat from their horizon and allows them to focus on secondary foreign policy objectives. ${ }^{15}$ This shift becomes dangerous when it exposes potentially militarizable conflicts of interest with fellow allies, often long-standing regional rivals. States discontented with the status quo spot an opportunity to further their aggressive ends, while satisfied states, suspicious of their longtime enemies' ambitions, replace the alliance's target with their rivals as the major security threat. The states' entry into the alliance disrupts the bonds born of shared fear, permits the prosecution of a conflict that the common threat had moderated, if not entirely hidden, and revives competition among the allies.

Second, membership in an institutionalized multilateral alliance often bestows greatly improved military capability on both the qualitative and quantitative dimensions, as more powerful alliance partners provide better equipment and training, more advanced weaponry, and larger numbers of weapons. Among states engaged in a limited dispute, these arms transfers exacerbate the security dilemma by creating suspicion that others harbor broader revisionist goals and by triggering a spiral of diplomatic tension.

Third, alliances, like other institutions, provide states with the means for issue linkage as well as with greater transparency, but such institutional functions need not yield cooperation and will contribute, under conditions specified later, to the deterioration of relations. Moreover, institutions are loci of power, and, rather than foster cooperation, the alliance can itself become the object of struggle as states seek to dictate its agenda, alter the distribution of benefits, and use its forums to generate political support. However, the central claim here-that alliance can deepen and intensify conflict among its members—-does not deny that some features of alliance mitigate disputes nor does it gainsay that great powers can use the allied relationship

accepts an idealized view of allied and adversarial dynamics, in which cooperation (or conflict) on a limited set of security questions leads to agreement (or disagreement) on all issues. Mercer 1996.

13. Snyder 1997.

14. That these arguments apply only to multilateral alliances, not bilateral relationships, limits their generality, although not their applicability to either the Greco-Turkish case or present-day East-Central Europe. Although history furnishes examples of multilateral alliances beyond NATO, this qualification means that many alliances will not exhibit the kinds of dynamics elaborated here.

15. For the sake of convenience and ease of expression, in this article I tend to present the alliance as essentially defensive in nature. But the propositions offered here should apply to both revisionist and security-oriented alliances. 
to ease tensions and prevent the outbreak of war. Rather, I seek to highlight the multiple, contradictory effects of international institutions.

I first present neorealist and neoliberal institutionalist insights into the consequences of alliance for potential conflicts among members. I explore in greater detail the logic of the realist institutionalist propositions laid out briefly earlier. I then examine the case of Greco-Turkish relations as a probe of these hypothesized dynamics. I conclude by discussing the implications of this analysis for NATO enlargement.

\section{International Relations Theory and the Consequences of Alliance}

\section{Structural Realism}

When faced with either superior power or a great threat, states wishing to survive and maintain their autonomy must balance through either internal means (by mobilizing resources) or external means (by forming an alliance) or some combination of the two. ${ }^{16}$ Alliances do not pattern state interactions but are essentially epiphenomenal intervening variables. In John Mearsheimer's stark formulation, "Realists maintain that institutions are basically a reflection of the distribution of power in the world. They are based on the self-interested calculations of the great powers, and they have no independent effect on state behavior." Alliances are short-term tools of foreign policy, easily dissolved and partners easily swapped, and allies can only occasionally constrain each other's behavior. ${ }^{17}$ Structural realists acknowledge that the NATO allies generally paid little attention to unequal gains during the Cold War, but the alliance, qua alliance, did not alleviate the European security dilemma. The key was the allies' fear of the Soviet Union, which drove the formation of the alliance and reduced relative gains concerns. Alliances are simultaneously central and peripheral to these theories.

Neorealists would clearly be highly skeptical that alliances bring stability to troubled regions, but they would be equally skeptical that alliances can prove destabilizing. International institutions, including alliances, matter only at the margins and cannot alter states' calculations regarding matters of considerable national interest. Thus, NATO enlargement would not influence the course of potential conflicts in EastCentral Europe, whether for good or ill. Although neorealists would reach these conclusions even when NATO appeared most effective, their arguments should seem more convincing in light of the disappearance of the Soviet threat. Agreeing with Kenneth Waltz that "NATO's days are not numbered, but its years are,"18 they pre-

16. Outside of the neorealist universe, states have many options beyond balancing: they can hide, transcend the politics typical of the anarchic international order, bandwagon with the stronger side, or tether themselves to the threat. But neorealism narrows the range of acceptable (and historically practiced) strategies to internal and external balancing. See Schroeder 1976 and 1994; Schweller 1994; and Weitsman 1997.

17. Mearsheimer 1994, 7. See also Waltz 1979; and Walt 1987.

18. Waltz 1993, 76. See also Mearsheimer 1990, 52; Walt 1987, vii; and Walt 1997, 171-73. 
dict that in the long term the alliance will become at best an empty shell, preserved for its public relations and symbolic value, in which members no longer fulfill core treaty commitments. ${ }^{19}$ Even if neorealists concede that heavily institutionalized alliances can influence state behavior, today's NATO, with its principal threat dissolved and its casus foederis unclear, would have only a minimal impact.

\section{Neoliberal Institutionalism}

A decade ago Robert Keohane insisted that "alliances are institutions." 20 Indeed, as Keohane briefly noted, the neorealist view does not describe the major postwar alliances, which possessed a relatively stable membership and acquired a formal bureaucratic organization with complex decision-making routines and differentiated functions. Were institutions epiphenomenal to the distribution of power, states would seem irrational for expending significant material resources and political capital on their formation and maintenance and on the subsequent battles for their control. Institutions, whether alliances or international economic regulatory agencies, shape the costs, information, even the preferences, and hence the actions of their constituent members.

Neoliberal institutionalists present several mechanisms linking institutional arrangements to the promotion of state welfare through international cooperation. ${ }^{21}$ First, rule-governed interaction encourages an increased number of transactions among participants, thereby discouraging cheating among states that are reasonably sensitive to the "shadow of the future." Second, by providing a framework for further agreement, institutions reduce the costs associated with the bilateral negotiation, monitoring, and verification of individual accords, making cooperation more profitable and attractive.

Third, institutions link issue areas, that is, different zones of state interaction, creating greater opportunities for side payments and raising the price of defection. As Keohane explains, "Clustering of issues under a regime facilitates side payments among these issues: more potential quids are available for the quo. Without international regimes linking clusters of issues to one another, side payments and linkages would be difficult to arrange in world politics." ${ }^{22}$ Such linkages also make cheating more costly because they provide the victim with multiple issue areas in which to exact revenge.

Fourth, institutions increase the level of transparency among members, raising the expected cost of cheating within an institutional context, as the likelihood of detection and retaliation increases. Moreover, the expected gain decreases, since transparency permits prospective victims to take protective measures. Fifth, institutions pre-

19. Regarding NATO's persistence and expansion after the Cold War, see Chernoff 1995; Duffield 1994; Hellmann and Wolf 1993; McCalla 1996; and Walt 1997.

20. Keohane 1988, 174.

21. The following discussion draws on Keohane 1984 and 1989; and Keohane and Martin 1995. See also Mearsheimer 1994, 342-53; Milner 1992; and Oye 1986.

22. Keohane 1984, 91. 
scribe regular interaction among individual decision makers and policymaking groups from member states, generating agreement on policy questions among participants, who then coordinate their respective states' policies. ${ }^{23}$ Even institutionalists outside the epistemic-community research program at times abandon their theoretical commitment to exogenous, fixed interests and aver that interaction can alter preferences over the long run.

Despite Keohane's plea, relatively little work has examined alliances from an institutionalist perspective, ${ }^{24}$ yet this approach yields expectations for intra-alliance relations. If in a neorealist world states are reluctant to remain in alliances longer than they must because they do not trust others, neoliberals expect that formalized, well-integrated alliances help their members overcome incentives to internal mobilization, attenuate the fear of unequal gains, and foster numerous cooperative ventures. Not all alliances have as deep an institutional form as NATO, however, and neoliberals would expect the degree of cooperation to correlate with the degree of institutionalization. For an alliance akin to NATO, evidence consistent with the institutionalist approach would reflect at least some of the following processes:

1. States use the issue-linkage opportunities provided by the alliance to offer side payments, eventually reaching a mutually satisfactory compromise.

2. Participation in alliance functions generates increasing knowledge of and trust in others' benign motives, decreasing concerns of relative gains and perceptions of intra-alliance threat. Further, if more powerful states provide military assistance, the state's absolute level of security rises.

3. Joint force structures and planning reshape each member's military posture to reflect alliance interests, reducing the fear of attack and obviating security dilemma dynamics. Force specialization constrains members' abilities to use their forces for exclusively national objectives.

4. Military officers that interact regularly with their allied colleagues are socialized into a shared alliance culture, transcending their national interest. ${ }^{25}$ These officials endeavor to shape their states' preferences accordingly.

\section{Common Flaws}

Thanks to simplifying assumptions regarding the interests of allies, neither structural realism nor neoliberal institutionalism is well suited to elucidating the politics within alliance. Neorealists typically portray international institutions as epiphenomenal to national power and alliances as fleeting agglomerations of capabilities: they are "only

23. This mechanism, however, lacks a theory explaining when and how transnational groups shape state preferences. Moreover, its idealized vision of a convergence of expectations among transnational experts hides the highly political process by which consensus is achieved. On epistemic communities, see Haas 1990 and 1992; and Milner 1992, 479.

24. Exceptions include Chernoff 1995; Duffield 1995; McCalla 1996; Wallander and Keohane 1998; and Weber 1992. For a balanced discussion, see Snyder 1990. A more constructivist work, containing important institutional elements, is Risse-Kappen 1995.

25. See McCalla 1996, 463-64; and Duffield 1994, 775 
temporary marriages of convenience, where today's alliance partner might be tomorrow's enemy, and today's enemy might be tomorrow's alliance partner." ${ }^{26}$ However, at times neorealists have implied that once states conclude that the international threat environment demands the formation of an alliance, their behavior exhibits a near identity of interest and residual clashes do not arise. Although Waltz famously noted that states "are compelled to ask not 'Will both of us gain?' but 'Who will gain more?" he also explained European integration as a consequence of the Soviet menace. Bound together by their common fear, Germany, France, and the other former great powers of Europe overcame centuries of hostility and strife and even welcomed their fellows' growth and development. Among these consumers of security, "not all impediments to cooperation were removed, but one important one was- the fear that the greater advantage of one would be translated into military force to be used against the others." 27

Yet, contra Waltz, states do not put aside their colliding interests when they enter into alliance. The decision to join forces reflects their common estimate of a particular threat, but they will continue to disagree on other matters and may pursue those goals with great vigor. For example, as a recent study of the early Cold War in Asia notes, "Although the United States and its allies agreed on the broad outlines of containment strategy, ... historians should be sensitive to the regional priorities of America's allies and to the subtle competition for spheres of influence that often underlined their diplomacy towards the Third World." As much as France supported U.S. efforts to counter the Soviet Union in Europe, it also perceived U.S. diplomacy in Vietnam as a threat to its overseas empire. ${ }^{28}$ Insofar as states continue to seek aims beyond the casus foederis of the alliance, they remain competitors on the international scene, blurring the distinction between allies and adversaries. Both of these neorealist strains of thought on intra-alliance relations fail to capture the complexity of states' motives and the resulting interactions.

On occasion neoliberal institutionalists have displayed greater sensitivity to this problem. In the context of a related debate, Keohane observed that "the concept of relative gains becomes fundamentally ambiguous as the number of actors becomes greater than two. Relative gains for state B in a dyadic relationship with state A may help state $\mathrm{A}$ in a contest with state $\mathrm{C}$, if $\mathrm{A}$ and $\mathrm{B}$ are allies and $\mathrm{B}$ and $\mathrm{C}$ are adversaries. Which 'relationship'counts?" However, rather than explore the interaction of absolute and relative gains within "cooperative clusters," such as alliances, neoliberal institutionalists fall back on the claim that such "defensive cooperation" allows groups of states to achieve relative gains collectively versus others and ignore the distributional consequences among themselves. ${ }^{29}$

Neoliberals commit a still more serious error by treating all institutions, regardless of the sphere in which they operate, as essentially identical. Although institutional-

\footnotetext{
26. Mearsheimer 1994, 11. This view is also reflected in neorealist analyses of buck passing.

27. Waltz 1979, 105, 70-71. I particularly thank Stacie Goddard for discussion on these points.

28. Lee $1995,7$.

29. See Keohane 1993, 276-77; and Snidal 1991. For a critique of both, see Grieco 1993. On the relative-absolute gains debate, see Baldwin 1993.
} 
ized alliances such as NATO do bring greater transparency, functional differentiation, and issue linkage, they also introduce dynamics that, though not entirely unique to security, are more accented in that domain. The stakes in individual plays of the security game, the potential costs of receiving the sucker's payoff, are much higher than in international political economy. ${ }^{30}$ Cooperation is more difficult in security because the gaps between particular payoffs in the prisoners' dilemma-between CC and DD, and DC and CD—are much greater; thus it would hardly be surprising that the consequences of membership in alliances would diverge from the findings of institutionalist scholars, who have usually studied environmental and energy regimes. Institutions remain critical for shaping the context in which states act, but they need not have the salutary effects liberals forecast. ${ }^{31}$

\section{Small Powers and Alliance: A Realist Institutionalist Approach}

\section{Shift in Foreign Policy Focus}

Small states, whether primarily revisionist or status quo, join alliances because they cannot attain their central values alone, and their success in achieving their aims depends less on their own capabilities than on the strength and credibility of their larger patrons. The participation of the small state may be important to the alliance: whereas it adds relatively little to the military effort per se, it may sit along a crucial strategic corridor or be of political and symbolic value. Through its very membership, it contributes to the alliance's position, but its national efforts remain largely insignificant to the project's success. Consequently, with the deterrence of the primary security threat (or achievement of the offensive goal) no longer falling on their shoulders, small-state decision makers turn inward and focus more intently on secondary concerns, particularly their long-standing conflicts with regional rivals. ${ }^{32} \mathrm{~A}$ shared threat will often lead states to overlook conflicts of interest and join in common cause, but membership in a multilateral alliance will effectively remove the challenge of coping with the threat from among the priorities of small-state decision makers, inducing a surprising shift in foreign policy, enabling conflicts that had previously been put aside, and returning the states to a world in which unequal gains are feared.

The paradoxical outcome- the alliance enhances the security of the small state even as the latter devotes little attention to the common objective-is familiar from

30. See Jervis 1983, 174-76; Lipson 1984; and Stein 1990.

31. Realist critiques of collective security as leading states down the path of war also treat international institutions as important sources of state behavior but remain skeptical about their impact. See Morgenthau [1948] 1993; and Betts 1992.

32. Along similar lines, see Jervis' discussion of the effects of NATO membership on Spanish foreign policy. Jervis 1997, 276. 
the logic of collective action, but the phenomenon of free riding has implications that extend beyond burden sharing to alliance members' interests and preference rankings. Thanks to this shift in foreign policy focus, revisionist states espy an opportunity to further their ends, and, for status quo states, the traditional rival replaces the alliance's target as the primary threat. And since states are very often satisfied with respect to some issues and less content with respect to others, they can exhibit both patterns of behavior. ${ }^{33}$

To abstract further, small states that join a multilateral alliance will undergo a pernicious transformation in their foreign policy agenda under the following conditions. First, the small state must have interests in conflict with its fellow ally, producing a dispute that is potentially militarizable. Second, these issues must be secondary to a more pressing foreign policy goal, whether offensive or defensive in nature. Third, the fact of alliance-often the provision of a security guarantee but also the joint commitment to particular revisionist aims-must ensure that the small state will attain its primary objective.

One implication of this analysis is that the less powerful ally will shift the focus of its foreign policy only if it need not fear abandonment by the more powerful allies. Doubts about whether the core members would honor their treaty commitments would keep small states attentive to the principal objective and limit the perverse consequences of alliance membership. However, large allies may have difficulty credibly threatening to abandon their fellows. ${ }^{34}$ Although the proposition that the more powerful ally is keener to maintain the coalition has generally been justified on inductive grounds, ${ }^{35}$ one can supply a more deductive logic: while the weaker power can bandwagon with the opposing great power, or perhaps transcend or hide from the conflict, its stronger partner has little option but to balance. Similarly, Snyder argues that the weaker state's very vulnerability generates its bargaining power: "A strong state will have a clear interest not only in the existence and independence of a weak partner, but also interest in acting to protect the partner, since the partner cannot defend itself. ... Therefore the strong state cannot credibly threaten to withhold support." 36 Moreover, the strategy of abandonment has significant potential costs: it invites attack if the adversary believes the threat, it may prompt the ally to look elsewhere for its security, and it may detract from a state's reputation for trustworthiness. Notwithstanding these difficulties facing the stronger ally, fears of abandonment should mitigate the hypothesized effect of the alliance on the small state.

33. Among midsize alliance members with long histories of conflict-such as France and Germany during the Cold War-one would not expect to see similar dynamics. Although they, too, cannot attain their goals without joining their resources to others, their national contribution to the alliance is key to the project's success. Since membership in the alliance does not render their national efforts superfluous, it would not foster the shift in foreign policy focus or diminish their sense of threat.

34. Olson and Zeckhauser offer a similar argument regarding the leader's threats to reduce its contribution. Olson and Zeckhauser 1966, 274.

35. Holsti et al. 1973.

36. Snyder $1997,170$. 


\section{The Internal Security Dilemma: From Dispute to Threat}

Before World War II, alliances were, with occasional exceptions, relatively simple, short-lived affairs. Military coordination was minimal, functional differentiation unheard of, formal organization unnecessary, and arms transfers relatively rare. But, with the Cold War, alliance became virtually synonymous with broader foreign policy coordination as well as military cooperation, the spread of advanced technology, and economic and military assistance. Most scholarship on alliances assumes that allies would welcome growth in each other's military capabilities, since increased strength in one would redound to the benefit of all. But the very means that contemporary alliances adopt to bolster their collective strength can, among their smaller members, have the opposite effect. Once alliance membership has prompted the state to turn its attention to secondary foreign policy objectives and thus to conflicts of interest with others, the arms transfers of the modern alliance play a critical role in the decline of relations between the two countries and in the transformation of a bounded dispute into a sweeping threat.

In the standard security dilemma, states cannot distinguish between the arms another state acquires to safeguard its defense and those it buys to perpetrate aggression. Always fearful for their own security, states must match their rivals' capabilities, leading to arms races and spirals of diplomatic tension. Each further purchase confirms to the other what it had already suspected: that the adversary is stockpiling weapons for an attack. In contrast, in the classic arms race scenario, states, seeking to prosecute their conflicts of interest, purchase increasing numbers of armaments in the competition for military advantage. ${ }^{37}$

The stylized case under examination here does not fall cleanly into either category. In the initial phase and even afterwards, the allied enemies do not build up their arsenals to achieve ends vis-à-vis each other but are supplied with weapons by the major allied powers for collective purposes. Nor, however, is this a pure security dilemma: defensive arms acquisitions alone are not sufficient for conflict, and the dispute is, at least initially, about something more tangible than fear of the other. ${ }^{38}$ Nonetheless, the case does exhibit important components of a security dilemma. A narrow conflict of interest-for example, over contested territory—does not imply a deep threat to national security: revisionist hunger pangs and snacking are distinguishable from an insatiable expansionist appetite. The resemblance to the standard security dilemma lies in the process by which the first is transformed into the second, in the spiral of deteriorating relations and broadening threat.

Among small states engaged in a dispute, the arms transfers of the modern alliance are a mixed blessing, simultaneously reassuring and threatening. Although the larger partners provide the arms to the allied adversary to meet shared objectives, its plans for using them remain partly inscrutable. Weapons intended for use against opposing forces can be turned against an ally. The standing conflict of interest raises questions about the other's commitment to the status quo, more broadly construed. Alliance

37. See Jervis 1976 and 1978; and Glaser 1997.

38. I am grateful to Chris Ball and Dan Nexon for alerting me to this point. 
military assistance compounds these suspicions, provides the capacity for offensive action, and thus contributes to a broader sense of insecurity.

Among states that recognize each other as defenders of the status quo, the intraalliance security dilemma, like that in the world beyond the alliance's boundaries, is manageable. But traditional rivals must suffer the burden of past mistrust and present conflict. With each convinced of the other's innate revisionism, cooperation will seem like foolish appeasement. Obeying the dictates of the deterrence model, each seeks to demonstrate resolve and, therefore, refuses to offer the concessions necessary for compromise. Cooperation becomes more difficult across the spectrum of contested issues, and the spectrum itself widens. The consequence of this spiral, as one scholar has written with reference to the Greco-Turkish disputes over the Aegean, is that although "it is possible to devise negotiating packages ..., this misses the point. It is not that there are Aegean issues that create tension between Greek and Turk so much as there are tensions between Greece and Turkey that make it all but impossible to resolve specific differences." 39

The security dilemma exists only when offensive and defensive postures and weapons are at least somewhat indistinguishable, and it is most intense and unstable when the offense has the advantage. ${ }^{40}$ Consequently, one might argue that if arms transfers and alliance missions do not increase the allied enemies'offensive capabilities, if the alliance assigns them limited and specialized roles, such as peacekeeping or air defense, and supplies and trains them accordingly, these arms would strengthen the alliance without exacerbating tensions. ${ }^{41}$ However, offensive and defensive weapons cannot be distinguished on a technological basis: all depends on their intended use within the reigning tactical concept. Armor did not seem ideal for offensive maneuver until the German blitzkrieg demonstrated its utility, and the best defense against the mobility of armor may be that model offensive weapon, the tank. Even fortifications (or an air-defense network), the classic example of a defensive technology, can serve a critical tactical defensive role within an offensive strategy, allowing the aggressor to build up its forces behind its lines with impunity or attack on another front. Although the alliance can shape the states' force structure, national planning for their use remains more insulated. The offense-defense balance is important, but it cannot be measured in structural terms, for it is itself the product of decision makers' strategic lenses..$^{42}$ The realization that weapons lack an intrinsic character and that conceptual innovations can relatively rapidly shift the advantage to the offense must leave small-state decision makers wary of arms transfers to their allied enemies. "Defense dominance" may be transitory, for the latest Guderian's ingenuity may overcome geographical constraints and imbue weapons with an offensive cast. Therefore, mili-

\footnotetext{
39. Haass 1988, 69.

40. Jervis 1978 .

41. Although he did not discuss alliance assistance, Evangelista suggests that a defensive reconfiguration would alleviate the tension between Greece and Turkey. Evangelista 1991.

42. See Mearsheimer 1983; Shimshoni 1990; and Levy 1984. These criticisms of offense-defense theory remain relevant notwithstanding the recent rebuttals and reformulations by Lynn-Jones 1995; Glaser and Kaufmann 1998; and Van Evera 1998.
} 
tary assistance of whatever nature seems likely to contribute to the deterioration of relations between the coalition's allied adversaries, assisting in the process converting a limited dispute into a broad security threat.

\section{Issue Linkage, Transparency, and Institutional Capture}

Issue linkage. Neoliberals argue that institutions promote cooperation by linking issue areas, which creates greater opportunities for side payments and compromise. Yet the additional issue areas supplied by the institution can also give states more to fight over, exploding the boundaries of an initially limited conflict. Rather than generate cooperation, institutions may, through issue linkage, actually contribute to the deterioration of the relationship. ${ }^{43}$ This outcome seems most likely when at least one of the states actually harbors revisionist aims or when at least one even suspects the other of being displeased with the status quo-conditions satisfied given the previous two hypothesized dynamics. Certainly revisionist states would seek to manipulate the issue-linking functions of institutions, broadening the conflict in the quest for greater gains. But the behavior of satisfied states, fearing what they perceive as their rival's revisionist tendencies, may result in similar patterns. ${ }^{44}$

Consider two allies, one of which believes the other has aggressive designs on a piece of its territory. To preserve the status quo, it will use the means at its disposal, including those provided by the alliance. To reduce the other's offensive capabilities, it may seek to persuade more powerful allies to restrict or halt military assistance or perhaps even economic aid. It may endeavor to limit its rival's operational responsibilities within the alliance. Skillful leaders will discover other means of safeguarding their state's interests through the institution. Fear of the other thus transforms limited conflict, imagined or real, into a larger political struggle, with ramifications for the states' respective military capability, economic potential, political capital, and international friendships. Although issue linkage may promote cooperation within a stable international environment, in a context of heightened suspicion it contributes to the intensification of conflict.

Transparency. Neoliberals argue that institutions increase transparency among their members, improving the quantity and quality of information and moderating the hazards of anarchy. By raising the expected cost of defection and lowering the expected profit, greater transparency nurtures cooperation. Yet this conclusion does not follow from the initial insight. Given the level of coordination in a modern alliance, secrecy regarding capabilities would seriously hamper the coalition's effectiveness, and allies generally have a fairly good sense of their respective military power. But such transparency regarding capabilities need not promote cooperation. First, if one rival is weaker than its allied adversary, excellent information regarding the

43. On the weakness of the logic connecting issue linkage and cooperation, see also Sebenius 1983; and Gowa 1989.

44. Keohane has himself briefly acknowledged, though only in a footnote, that in highly conflictual situations, "linkages . . . may well impede cooperation." Keohane 1989, 18, n.20. 
other's military superiority will do little to allay its concerns. Second, such information may not improve a state's defensive capabilities against a surprise attack in a limited campaign; protective measures may simply be impossible in the face of surprise, and the expected gains from cheating will then be unaffected ${ }^{45}$ Third, one may not be able to infer much from another's capabilities and force structure. The same troops that pose a threat to the contested territory may be justified on the basis of alliance-related tasks. For example, in the early 1980s, Athens portrayed the Turkish Fourth Army, the so-called Army of the Aegean, as a standing invasion force, whereas Ankara claimed it was used primarily for training purposes, with few personnel permanently attached. While Greece portrayed the landing craft based near Izmir as a threat to its Aegean islands, Turkey argued that the landing fleet must be stationed on its west coast to ferry troops between Asia and Europe in case of war with the Warsaw Pact countries. ${ }^{46}$ In such cases, estimates regarding the adversary's intent derive less from accurate information regarding its forces than from worst-case analysis and the weight of the past.

Although alliance membership improves the quality of data on the other state's capabilities, for a variety of reasons it may be less helpful in discerning the state's intentions. First, transparency may simply provide greater access to the multiple opinions floating around the other's halls of power, leaving the fog of foreign policymaking as dense as ever. Second, though intra-alliance communication may reveal how the ally plans to use its forces in support of alliance objectives, it may not lift the shroud concealing plans for military operations in support of national aims. In the absence of extensive espionage networks, such plans can be kept secret and restricted to a handful of top staff. Third, even if institutions did yield clear answers regarding the other's motives, they might provide conclusions that militated against cooperation. Fourth, superior capabilities might seem threatening even in a status quo state; a rapid change in government, particularly through a coup, may not leave enough time to compensate for weaknesses.

Neoliberal institutionalist claims regarding the virtues of transparency are indeterminate. Often intra-alliance transparency will yield just slight gains in the struggle against the uncertainty of anarchy. And, at times, when improved information reveals that one's ally has formulated aggressive designs, transparency serves to inhibit cooperation.

Capture. Institutions are not apolitical venues through which states achieve agreement. They are sources and instruments of power, and thus the institution itself, rather than cultivating cooperation, becomes the site and object of contest. As Edward Mansfield notes, states have significant incentives to capture institutions for their ends "because they can generate power for those that control them. Actors that gain power within an institution have the ability to set its agenda and influence the

45. On surprise attack, see Betts 1982; and Mearsheimer 1983.

46. McDonald 1988, 73-74 
distribution of benefits and costs among members." ${ }^{47}$ Small states are generally incapable of fully controlling and transforming institutional agendas, but they can nevertheless capture them from the perspective of the bilateral rivalry. They seek to raise the issues separating them in institutional forums, soliciting condemnation of their fellow ally's aggressive behavior. They endeavor to persuade the alliance to adopt their perspective of the struggle and issue pronouncements endorsing that view or to exclude their rival from institutional benefits and thereby achieve a relative monopoly. In this fashion, a small state can harness the institution's power to pursue its political ends.

In conclusion, these realist institutionalist hypotheses endorse the neoliberal belief in the power of international institutions to shape state behavior, yet remain dubious about their effects. Alliances, despite their features that promote stability and cooperation, can also spur competitive dynamics. Two caveats deserve mention. First, these hypotheses do not pretend to explain all the flux in the allied enemies' relations, which will doubtless improve and worsen for a variety of reasons over time. My claim is merely that membership in an alliance will, under the conditions specified earlier, likely spur heightened tensions. Second, a realist institutionalist approach must also recognize that certain features of alliances do promote cooperation. The alliance does generate dependency and hence gives the larger partners, which have an interest in high alliance cohesion and stability, some influence over their smaller allies. The interaction of certain segments, particularly high-level military commanders, will nurture a greater sense of understanding and trust among these rival elites. The military will also doubtless be more sensitive to the demands of the central alliance powers. Although the propositions developed here focus on the competitive dynamics set off by alliance membership, they remain open to the various and inconsistent effects of institutions; a more complete analysis would devote greater attention to the net effect.

\section{Realist Institutionalist Dynamics in the Greco-Turkish Conflict}

During the Cold War and since, the Atlantic alliance's southern flank has been riven with conflict-from the emergence of the Cyprus issue in the mid-1950s, to the politicization of NATO operational responsibilities in the late 1970s and beyond, to the Aegean Sea disputes of the past three decades. For both neorealist and neoliberal theories, that Greece and Turkey have approached war on several occasions poses a challenge. Neorealists would predict alliance cohesion to correlate with the intensity of external threat and, therefore, would expect NATO members to adopt more national policies during periods of superpower détente, but they cannot explain why at the height of the Cold War Greece and Turkey, though fearful of the Warsaw

47. Mansfield 1995, 600. 
Pact, prosecuted their conflict with such vigor. Nor can neoliberal institutionalists understand the persistence of this deep-seated rivalry in the face of alliance, with all its incentives toward cooperation; after over two decades of friendship and after joining the organization in 1952, Greece and Turkey revived a long-dormant dispute, extending it to new issues and deepening their mutual hatred. Although the case seems a prime candidate for theoretical exploration, work on alliances has generally treated it, and other instances of serious intra-alliance tension, as exceptions to the rule. $^{48}$

For both these perspectives on alliance, the Greco-Turkish case should have been easy. The intensity of the Soviet threat and the high level of institutionalization within NATO should have ensured continued stability in the region. Yet the persistence of conflict does not automatically corroborate the realist institutionalist propositions elaborated earlier. Whether Greece and Turkey's accession to NATO left the course of their relations largely unaltered, alleviated or exacerbated tensions between them, or cut both ways are questions that cannot be resolved by this simple observation. The following case study focuses on the hypothesized intervening processes to understand the effects of alliance on conflicts among members and thus serves as a plausibility probe for these hypotheses. Like all theoretical propositions, these were not constructed in a vacuum but involved both deductive and inductive reasoning. The broad outlines of the Greco-Turkish case inspired consideration of the relationship between alliance and conflict but did not determine the hypotheses. ${ }^{49}$

\section{Cooperation Within Historic Hostility}

With their national myths recalling ancient wars, Greece and Turkey have shared an abiding distrust and enmity. The modern period of hostility is rooted in the Greek struggle for independence from the Ottoman Empire over the course of the 1820s, the steady Greek territorial gains at the declining empire's expense over the next century, the crushing defeat of the Sultan in World War I, and the harsh terms of the Sèvres Treaty, which rewarded Greece for its loyalty to the Allies, culminating in the Turkish War of Independence, which was brought to an end by the Lausanne Settlement of 1923. This bitter past spawned deeply ingrained resentments and popular stereotypes that still serve as the lenses through which the two peoples perceive and interpret each other's behavior. For many experts on the region, these deeply rooted prejudices are the driving force behind the postwar Greco-Turkish conflicts. ${ }^{50}$

Nevertheless, a spirit of détente emerged in 1930. Guided by two powerful and charismatic leaders, Eleuthérios Venizelos and Mustafa Kemal Atatürk, Greece and

48. One comprehensive literature review noted merely that "the split between Greece and Turkey over Cyprus may serve as an example of how a local conflict can contravene the alliance configuration created by the dominant international cleavage." See Holsti et al. 1973, 100-101.

49. Thus the following study is closer to a plausibility probe than a deviant case analysis. Either way, further assessment of the propositions' explanatory power is warranted. See Eckstein 1975, 108-13; and Lijphart 1971, 692.

50. Stearns 1992. 
Turkey settled territorial questions left outstanding in Lausanne and resolved disputes on the terms of population exchange. Although they no doubt sought to reap the benefits of a newfound amity - the end to a costly arms race and the ability to concentrate on domestic priorities-it was a shared threat that allowed them to overcome their mutual suspicion, which had persisted throughout the 1920s. Faced with the rising power and revisionist ambitions of Bulgaria and Italy, Greece and Turkey reconciled their differences because they felt they had little choice. These ties deepened over the next decade but were tested during World War II. Turkish neutrality struck Greeks as a betrayal of their hard-won trust, and Turkey's imposition of a wartime tax that fell especially heavily on minorities introduced further stress into the relationship. But perhaps most damaging was the revelation, raising doubts about Turkey's commitment to the territorial status quo, that the Allies and Axis had respectively sought to entice Turkey to enter the war or remain on the sidelines by bribing it with Aegean islands to which Greece laid claim. ${ }^{51}$

After World War II, each confronted a major communist threat-Turkey directly from the Soviet Union, and Greece from both Bulgaria and its internal communist guerrillas - and the cooperation of the interwar period resumed. Linked by the Truman Doctrine, both sent troops to Korea, and both joined NATO in 1952. The Greek king and queen traveled to Istanbul and Ankara in June 1952, and Turkish president Celal Bayar paid an official visit to Greece six months later. Greek prime minister Nikolaos Plastiras floated the possibility of union, ${ }^{52}$ and Bayar declared that they represented "the best example of how two countries who mistakenly mistrusted each other for centuries have agreed upon a close and loyal collaboration as a result of the recognition of the realities of life." ${ }^{53}$ Greece and Turkey reached the apex of their postwar détente in 1953 when they, along with Yugoslavia, signed the Balkan Treaty of Friendship and Cooperation, which was formalized into a mutual defense pact the following year. As one scholar has observed, "As long as Greek and Turkish interests coincided, as they did for nearly a decade after the Second World War, there was no reason why their warming relationship could not have made further progress. This is what could reasonably have been expected in the early 1950s given their fear of the Soviet Union and commitment to the Western Alliance." ${ }^{54}$ Yet events soon exposed the fragility of the relationship. Over two decades of friendship were thrust aside as enosis (union) with Cyprus rose to the top of the Greek national agenda.

Why did the Greco-Turkish détente dramatically collapse? Although Cyprus was obviously a critical factor, mainstream accounts suggest two reasons the countries failed to forge a satisfactory compromise as they had on equally divisive issues in the past. First, both lacked leaders of the stature of Venizelos and Atatürk, whose nationalist credentials had permitted them to overcome opposition criticism and offer major concessions. Second, Cyprus indicated that "each country assessed its vital interests

51. See Psomiades 1968; Bahcheli 1990, 9-15; Coufoudakis 1985, 186-88; and Papacosma 1984, $298-99$.

52. Clogg 1991, 13.

53. Bahcheli 1990, 16

54. Ibid. 
on the basis of regional concerns, rather than the global considerations that guided American policy. Consequently, American appeals for Greek-Turkish cooperation and unity in view of the Soviet-American confrontation increasingly lost their impact in both countries." To explain the timing of the emergence of enosis, historians have asserted that the Greek government delayed formally espousing the Cypriot cause until 1953 because of its dependence on Britain and the United States. ${ }^{55}$

Although these arguments certainly have some merit, they cannot account for the transformation in Greek and Turkish priorities after World War II. First, if regional interests, rather than the Cold War, determined the pair's foreign policies, why in 1947 had Turkey not opposed Greece's incorporation of the long-contested Dodecanese island chain, strategically located off Turkey's southeastern coast? ${ }^{56}$ Yet if the Soviet threat had bound them together, sparking a renewed détente and suppressing conflicts, why did they, just eight years later, find unresolvable a similar territorial dispute? Second, unless Greece and Turkey believed that their security did not depend on the outcome of the contest between the United States and the Soviet Union, unless neither feared the eastern bloc, the Soviet Union and its satellites should have figured even in their exclusively "regional" calculations. Unlike a decade later, in the mid-1950s Americans and Europeans generally agreed that the Soviet threat had not abated, and thus the eruption of the Greco-Turkish conflict over such relatively petty concerns remains surprising. Finally, dependence on foreign powers did not prevent Greece from earlier adopting an enosis policy, because in 1953, three years after the Cypriot plebiscite in favor of union, Greece was, if anything, more reliant on others, particularly the United States, for its external security and economic rehabilitation. What had changed was that Greece and Turkey had been admitted to NATO, and the hypotheses elaborated earlier provide insight into these developments.

\section{NATO and the Revival of Greco-Turkish Strife}

By the late 1940s Greece and Turkey, fearful of Soviet designs, pressed the United States for a security commitment. Although Turkish officials acknowledged that domestic politics played into their demands as much as did strategic considerations, they plausibly and repeatedly insisted that the presence of Western military facilities on their territory had made their country into a magnet for Soviet attack. The United States feared the Turks would opt for neutrality unless it conceded and offered Turkey a place in the young alliance. Although observers from the Pentagon were impressed by the Turks' anti-Soviet enthusiasm and reputation for battlefield ferocity, Washington policymakers saw Turkey as valuable primarily for its airstrips from

55. Coufoudakis 1985, 189, 191.

56. Although Turkey was, as some have argued, in a relatively weak postwar bargaining position as a late entry into the Allied coalition, it had conceded the islands to Greece as early as 1943, apparently in exchange for assurances that Greece had abandoned its own revisionist aspirations. Although Turkish motives are not clear, it is certainly plausible that Turkey, unsure of the war's ultimate conclusion, believed it could not afford, given the threatening and uncertain international environment, to antagonize its Aegean neighbor. See Papacosma 1984, 300; and Bahcheli 1990, 15, 31. 
which U.S. bombers might conduct strikes against Soviet targets and for its strategic location controlling Soviet entry into the eastern Mediterranean. U.S. strategic planners hoped Turkish troops could retard a Soviet attack and lessen the vulnerability of the Persian Gulf and Suez Canal, but most importantly Turkey provided access to important Soviet facilities and delivered a commanding naval position. ${ }^{57}$ The smaller NATO allies objected to further stretching the "North Atlantic" to include what Dean Acheson called "a snake pit of troubles" in the Levant, but such was considered Turkey's importance, particularly in light of Korea, that in 1951 substantial U.S. diplomatic effort went into wringing from them an invitation to Greece and Turkey. ${ }^{58}$

Membership in NATO rendered irrelevant Greek and Turkish national efforts to ensure their security vis-à-vis the Soviet bloc, providing these relatively small states with incentives to ride free on the efforts of their more powerful allies and to shift the focus of their foreign policy from the Soviet threat to their more parochial conflicts. Although President Truman had publicly committed the United States in 1947 to protecting Greece from communist subversion, U.S. national security planners had refused, as late as February 1951, to promise a military response in the case of a Soviet bloc attack on Greece. ${ }^{59}$ After 1952, with the Atlantic alliance guaranteeing its security, Greece believed itself able to pursue its longtime dream of union with Cyprus, and, shortly after its accession, the Greek government, which had considered enosis its eventual goal but had long resisted domestic pressures for immediate action toward that end, officially endorsed that policy. ${ }^{60} \mathrm{Had}$ Greece remained outside the alliance, it could hardly have devoted the resources or foreign policy attention to so peripheral an aim. Cyprus began to occupy a central place in the nation's imagination because an outside party had met the core security need.

Like Greece, Turkey had assigned its regional interests a low priority before joining the alliance. Its muted response toward the growing Cypriot clamor for enosis had understandably led Greek decision makers to conclude that Turkey was not concerned with the island's future. ${ }^{61}$ Moreover, in light of both countries' commitment to the alliance, Greece had not foreseen Turkey's fears of encirclement if Cyprus came under Greek sovereignty. Turkish leaders often cautioned Greece not to press for union, but they invariably paired these warnings with affirmations of abiding GrecoTurkish friendship. For example, in 1951 the Turkish foreign minister tempered his remarks by stressing that the issue was harmful "especially at a time when serious threats to the very existence of the free world make it imperative for all free and friendly nations to stand together unreservedly." As Greece began aggressively pressing its Cyprus agenda in the United Nations in mid-1954, Turkish prime minister

57. U.S. policymakers gave much less consideration to Greece, in part because they did not foresee Greece, entrenched in a civil war with communist-supported guerrillas, as viably pursuing neutrality. Nevertheless, concessions to Turkish demands necessitated matching commitments to its Aegean neighbor.

58. See Leffler 1992, 289-90, 353, 419-20; and Acheson 1969, 569-70.

59. NSC 103, cited in Roubatis 1979, 47.

60. On the enosis movement in Greece and the government's complicated postwar relationship with it, see Bahcheli 1990, 28-31, 34-36; and Barham 1982. For a discussion of tentative postwar Greek efforts to revise the Cyprus status quo, see Xydis 1967.

61. See Coufoudakis 1985, 192-93; and Bahcheli 1990, 35-38. 
Menderes was reportedly guilty of speaking critically of Greek foreign policy in public, while privately assuring Greek representatives that Cyprus could not disrupt the bonds between their countries. ${ }^{62}$

Turkey failed to issue clear signals regarding Cyprus in part because its interests were in flux-that is, its membership in NATO encouraged Turkey, as it had Greece, to consider a more active role in regional affairs. By December 1954 the ambiguity surrounding Turkish feelings had disappeared, and the country's ambassador to the UN firmly declared that Turkey must be party to any agreement revising the status quo on the island. In 1955, when Britain, to balance Greek pressure, offered Turkey a place at the London Tripartite Conference regarding Cyprus, Turkey seized the opportunity. As the meeting came to an inconclusive end, Turkey indicated its intense interest in the island's fate by engineering destructive anti-Greek riots in Istanbul and Izmir. Paradoxically, their accession to NATO led Greece and Turkey to redefine their interests in ways that strained the alliance commitment, bringing them into tension with each other and with their more powerful allies.

Two early U.S. efforts to prevent conflict over Cyprus illustrate NATO's curious effects on the pair's foreign policies. In the aftermath of the 1955 riots, Secretary of State John Foster Dulles dispatched identical letters to the two parties, urging them to put aside their differences for the sake of coalition unity and subtly threatening to terminate U.S. assistance unless they could subordinate their national objectives to the greater good of the free world. The prospect of losing U.S. aid was no doubt terrifying to these weak governments, but their security against Soviet attack remained assured by the North Atlantic Treaty. Although his warnings promised to exact a great cost, Dulles' pleas were dismissed on both sides of the Aegean.

In contrast, during the 1964 crisis, after Turkey had informed the United States that it planned to intervene in the intercommunal warfare ravaging Cyprus, Lyndon Johnson sent Prime Minister Inönü "the most brutal diplomatic note" UnderSecretary of State George Ball had ever seen. ${ }^{63}$ Not only did Johnson remind Inönü that the use of U.S.-supplied equipment in such an operation would violate their 1947 military assistance agreement, but he also threatened to deprive Turkey of NATO protection. "I hope you will understand," he wrote his Turkish counterpart, "that your NATO allies have not had a chance to consider whether they have an obligation to protect Turkey against the Soviet Union if Turkey takes a step which results in Soviet intervention without the full consent and understanding of its NATO allies." Removal of the NATO guarantee was not a quantifiable cost, like the loss of U.S. aid, but it exposed the nation to the unthinkable—overwhelming attack, devastation, the reconstitution of society along the Soviet model. Johnson's threat forced Turkish decision makers to think like the leaders of a country outside the alliance, and, not surprisingly, Cyprus hardly then seemed a priority. His letter had the desired effect: invasion, and the broader war that had seemed sure to ensue, were averted. ${ }^{64}$

62. Bahcheli 1990, 36; and Xydis 1967, 9-11, especially n.21.

63. Ball 1982, 350.

64. The standard view is that Johnson's letter prevented war; see, for example, Harris 1972; Camp 1980; Alford 1984; Bahcheli 1990; and Constas 1991. Although not disputing the United States' critical 
Historians of the conflict have often implied that before 1974, when Turkish forces landed on Cyprus, neither country viewed the other as a significant menace to the security of the mainland, that the dispute over the island remained quite limited. ${ }^{65}$ However, the realist institutionalist propositions presented earlier expect that such thinking would have reemerged within NATO's southeastern flank far before that date. Notwithstanding the standard account, by the mid-1950s the conflict was perceived as having broader implications for the two states' security relations. As the dispute over Cyprus wore on, Greco-Turkish relations spiraled downwards in late 1956 and early 1957 as the two countries tangled over the status of the island and the treatment of minorities. Turkish leaders gave voice to their traditional fears of encirclement through Greek control over the Aegean. Meanwhile, in April 1957 the conservative, pro-American Greek premier Constantine Karamanlis angrily told U.S. ambassador George Allen that he had lost patience with Turkish provocations and with its threats to seize Greek islands in the Aegean: consequently "the Greek government was obliged, regardless of the alliances of which it remained a member, to start exploring in what way and through what combinations it could face the contingency of a war with Turkey." 66

As early as 1957 the revised Greek threat analysis had crept into U.S. policy statements, which now referred to Greek "suspicions of Turkey and its fear of Turkey's entrenching itself as the chosen instrument of U.S. policy in the area" and considered Turkey not Greece's ally, but its "ancient enemy." By late 1958 the United States recognized that "Greece's determination to maintain approximate military parity with Turkey has increased as relations over Cyprus have worsened." 67 Although the militarization of the eastern Aegean islands has acquired prominence only since 1974, Greece first placed troops on those islands, debatably in violation of the Lausanne Treaty, in 1960. Turkish officials have often described the militarized islands as "daggers" pointed at the mainland and have portrayed them as launch sites for air strikes, but Greeks counter that they deter Turkish aggression in the Aegean. Within five years of the first Cyprus crisis, Greece had initiated restructuring its military forces to cope with a broad Turkish threat to its national security. ${ }^{68}$ Recently,

role, Bolukbasi maintains that Inönü's insistence on a U.S.-brokered settlement was the key to U.S. leverage over Turkey. Bolukbasi 1993. In contrast, Couloumbis argues that Turkey lacked the training, equipment, and strategic position to conduct an amphibious invasion in 1964 and that its capabilities would have permitted only limited air strikes. Couloumbis 1983.

65. See Coufoudakis 1985 and 1991; and Hatzivassiliou 1995. Others date the shift in Greek threat perception to the near-invasion of 1964, arguing that afterwards both took seriously the possibility of outright war and that a consensus emerged within Greece that Turkey harbored revisionist ambitions. See Clogg 1991; and Platias 1991.

66. Xydis 1967, 78-96. For some examples of the action-reaction spiral in Greco-Turkish relations, see ibid., 616-17, n.38. The reconstruction of the Karamanlis-Allen conversation is in ibid., 84-86.

67. Statement of U.S. Policy on Greece (NSC 5718/1), 5 August 1957, FRUS 1955-1957, vol. 24, 587; Embassy in Greece to Department of State, 4 November 1957, FRUS 1955-1957, vol. 24, 598; OCB Report on Greece, 17 December 1958, FRUS 1958-1960, vol. 10, pt. 2, 648.

68. Bahcheli 1990, 146-49. However, Greece's attitude toward Turkey remained highly complex. Even in July 1958 the Greek General Staff informed Karamanlis that, in case of Soviet bloc attack, Greece would, absent Turkish assistance, be unable to maintain its position and that, if Greece fell, Turkey would be finished, geographically isolated from other NATO forces. See Hatzivassiliou 1995, 191. 
Greek foreign minister Theodoros Pangalos described well the thinking that has dominated Greco-Turkish relations over the last forty years: "We Greeks," he said, "must get over the old knee-jerk reaction that if something is bad for Turkey, it is good for us." 69

As Greece and Turkey increasingly viewed each other as regional competitors, the alliance's military assistance and training exacerbated their security relations. According to a former U.S. ambassador to the region, "The most questionable hypothesis underlying our Greek and Turkish aid programs is . . the pretense that we have been arming them against an outside threat rather than against each other." 70 Karamanlis voiced his concerns about disproportionate U.S. aid to Turkey as early as October 1955, just a month after the Istanbul riots. "Many Greeks," he further told General J. Lawton Collins, the U.S. representative to NATO's Military Committee and Standing Group, "regard with trepidation the important role Turkey seems to have in Western military and political plans." ${ }^{71}$ Even as Greece and Turkey were negotiating a Cyprus settlement, the counselor of the Greek Embassy in Washington complained to a State Department official that Greece was the victim of "favoritism shown towards Turkey in the military preparedness of NATO . . , in the supply of equipmentabove all, naval equipment." Although Greece understood that the allies were arming Turkey to fulfill alliance tasks, "the Greek people could not help but think of Turkey's growing military strength in terms of her 'unfriendly' attitude towards Greece and the centuries of Greco-Turkish conflict which lay behind it."72

By May 1958 U.S. officials acknowledged that giving Turkey more advanced aircraft (F-100s) than Greece (F-84s) would "aggravate" Greek fears that Turkey was of greater strategic consequence to the United States than Greece-not that the observation had any effect on U.S. assistance levels. Later that year, the Operations Coordinating Board, searching for a way to lower the cost of modernizing Greek forces in accordance with the NATO planning document MC-70, considered the possibility of "reducing those [Greek] national forces which are in excess of MC-70 goals." However, it also recognized that "Greek political considerations, especially Greek sensitivity regarding the Turkish military position, may cause Greece to resist any proposals to pare its conventional national forces and limit military buildup plans." ${ }^{73}$ These observations by U.S. leaders and bureaucrats are an indirect, yet particularly powerful, form of evidence. Accustomed to viewing the world through the lens of the Cold War, by a light refracted by their own interests, Americans could

69. In Kurop 1998.

70. Stearns $1992,43$.

71. Army Attaché in Greece to Department of Army, 13 October 1955, FRUS 1955-1957, vol. 24, 547-49. Collins' reply is revealing: first, he averred, war between NATO allies is unthinkable in light of the common Soviet threat, and, second, U.S. aid is unequal because the common defense prescribes different roles for the two countries. Such arguments hardly reassured Karamanlis.

72. Memorandum of Conversation Between Cavalierato and Williams, 24 March 1958. FRUS 19581960, vol. 10, pt. 2, 611-12. Such arguments regarding the Turkish threat must have been sincere, since they could hardly have been expected to help the Greek cause. If one wanted aid from the United States, one stressed the Soviet menace, not fear of an ally.

73. OCB Report on Greece, 14 May 1958, FRUS 1958-1960, vol. 10, pt. 2, 619-20; OCB Report on Greece, 17 December 1958, FRUS 1958-1960, vol. 10, pt. 2, 643-44. 
not comprehend the nature and depth of the conflict: why, they asked themselves and their troubled allies, could Greece and Turkey not reclaim the spirit of Venizelos and Atatürk? In U.S. officials, who were slow to shed their presuppositions, one finds strong proof that by the late 1950s — far before most historical accounts suggestthese allies were also adversaries, for whom distributional questions were critical, and that alliance military assistance fueled the tensions between them.

The alliance's priorities during the Cold War exacerbated this problem. At first the United States believed that Greece's main security concern was internal and supplied it with an army capable of crushing the communist insurgency and deterring further civil war, while Turkey was armed to resist a direct Soviet attack. Greece was to have sufficient military capacity to slow Soviet bloc forces until NATO reinforcements could arrive. ${ }^{74}$ Although Greece initially received greater assistance than Turkey, the resolution of the civil war reversed the pattern. Between 1952, when both states entered NATO, and 1959, when they negotiated a short-lived Cyprus settlement, Turkey received over twice as much U.S. military assistance as Greece $(\$ 1.36$ billion to $\$ 673.9$ million)—a trend that continued throughout the $1960 \mathrm{~s} .{ }^{75}$ Consequently, before 1974, Greece's forces, lacking strong air and naval components, remained little more than a trip wire in case of Soviet attack, whereas Turkey developed a well-rounded force capable of an independent offensive campaign. Insensitive to local tensions because of its focus on the Soviet bloc, the alliance-particularly the United States - created a marked imbalance of power in the Aegean that threatened regional stability. ${ }^{76}$ Although U.S. executive branch officials long criticized Congress' rough enforcement of the 7:10 ratio in assistance to Greece and Turkey, both because it limited the administration's options and because of its arbitrary nature, the 1978 amendment to the Foreign Assistance Act of 1961—specifying that U.S. aid to Greece and Turkey should "be designed to insure that the present balance of military strength among countries of the region ... is preserved"- -brought a greater measure of stability to the area by disbursing aid more evenly than in the past.

\section{Issue Linkage and Institutional Capture}

Although neoliberal institutionalists associate issue linkage with cooperation, observers of the Greek-Turkish conflict have noted its drawbacks. In the words of one, "Instead of enabling them to reconcile their differences by direct negotiation, their common alliance with the United States and Western Europe often appears to act as

74. See Roubatis 1979; and Veremis 1984, 32-33

75. Couloumbis 1983, 178. Slightly different figures, although along the same general pattern, are in Botsas 1988, 253.

76. Greece's security situation was further complicated by its lack of strategic depth in the east and north, its long border, and the vulnerability of its Aegean islands, located closer to the Turkish mainland than to its own. Although, as argued earlier, the offense-defense balance cannot be ascertained without greater information regarding Greek and Turkish doctrine, it seems plausible that these geographical conditions laid the foundation for offensive advantage and, combined with the disparities in power, contributed to the region's instability. See Platias 1991, 95-97; for a more detailed analysis of the local geography and military balance, see Brown 1991, 127-33. 
an impediment. Bilateral disputes acquire a multilateral dimension."77 Van Coufoudakis has advised that "an attempt should be made to decouple some of the issues and to seek solutions to problems that appear to be manageable." 78 Not only did NATO help revive the dormant Greco-Turkish feud at the height of the Cold War, but also its vaunted mechanisms of reconciliation have served to intensify the disputes. Rather than treat the multiple issue areas the alliance has brought together as an opportunity to exchange concessions, the two countries have, in their quest for bargaining leverage and out of fear of establishing a reputation for weakness, sought to manipulate these linkages to their political and strategic advantage, broadening the conflict and producing escalating levels of tension. The following incidents do not represent a full catalog, but are intended merely as illustrations of the dangers of issue linkage in the context of international rivalry.

From 1977 on, Turkey used its veto to block Greece's reentry into the military wing of the alliance- the latter had withdrawn after NATO refused to take action in its defense in 1974-insisting that its reincorporation be contingent on the negotiation of new operational control responsibilities in the Aegean. Turkey hoped to revise the pre-1974 arrangements, which had given Greece responsibility for the bulk of the Aegean and split the sea down the middle. Greece objected that such an arrangement would leave Turkey responsible for the security of hundreds of Greek islands. Several plans put forward by NATO supreme commanders Alexander Haig and then Bernard Rogers floundered on the shoals of Greek-Turkish suspicion. After the military takeover in 1980, Turkey withdrew its demand, and Greek reentry was allowed to precede the renegotiation.

On coming to power in 1981, Prime Minister Andreas Papandreou pressured NATO for a guarantee of Greece's eastern borders, and at the 1981 defense ministerial he insisted that the communiqué acknowledge Greece's position that Turkey posed the greatest threat to its security. When the alliance refused, Papandreou blocked the issuance of a joint communiqué, the first time a ministerial had ever failed to produce such a document. ${ }^{79}$ Moreover, at the 1982 meeting of the NATO ministerial council, Papandreou personally handed out a memorandum detailing Turkish infringements of Greek airspace.

Turkey has objected to Greece's militarization of Lemnos, near the strategic choke point of the Dardanelles, and has successfully excluded the island from NATO exercises. Consequently Greece has regularly boycotted allied military maneuvers in the Aegean since its return to NATO in 1981 and, although nominally reintegrated into the alliance's military wing, has not assumed an active role in its expected primary area of operations. As a consequence of the Lemnos impasse, Greece and Turkey did not for several years formally commit troops to NATO, and Greek forces did not participate in any NATO maneuvers in 1986 (they had previously taken part in exercises outside the Aegean). ${ }^{80}$

77. Stearns 1992,5 .

78. Coufoudakis 1985, 215.

79. Veremis 1984, 37.

80. See Clogg 1991; and Meinardus 1991. 
Nor has this competition been limited to NATO: Greece and Turkey have engaged in similar behavior in other international organizations. Since Greece joined the European Community (EC) in 1981, the EC has repeatedly condemned Turkey's recognition of the independent Turkish Republic of Northern Cyprus, and the European Parliament has adopted a resolution warning that "the unlawful occupation of part of the territory of a country associated with the community (i.e., the Republic of Cyprus) by the military forces of another country, also associated with the Community (i.e., Turkey), presents a major stumbling block to the normalization of relations with the latter, viz. Turkey." The EC listed the continuing Greco-Turkish and Cyprus conflicts as among the reasons for its refusal to consider Turkey's 1989 application. Greece has successfully exploited its monopoly in the EC arena to garner political support in its bilateral dispute, and its capacity to block Turkish entry into the Community (and later the European Union, EU), has provided it with a powerful lever with which to wring concessions from Turkey. ${ }^{81}$

Institutions, as loci of power, themselves become the object of struggle as rivals seek to capture their forums and mechanisms. Until the 1980 coup, Turkey sought to parlay its exclusive presence in NATO's military wing into bargaining power. Conscious of the alliance's utility as a political tool, both parties have at times remained in NATO less out of a commitment to its fundamental goals than because membership allows them more effectively to mobilize political support on key issues and to prevent collective NATO decisions that would undermine their respective positions. As one Turkish analyst bluntly explained, "If Turkey were not a member of NATO, or had she left NATO while Greece remained a member of the alliance, this would tip the power balance in favor of Greece and weaken the Turkish stand on Cyprus," since the Western powers would necessarily endorse the Greek position. ${ }^{82}$ Speaking on the floor of the Greek Parliament in 1987, Papandreou similarly averred, "We shall not withdraw from NATO because our country's security dangers within the Washington-Ankara-Athens triangle will be deadly." 83

\section{Transparency}

As members of the same alliance, Greece and Turkey have had fairly accurate knowledge regarding their respective military capabilities. As expected, however, such transparency has not been sufficient to promote cooperation. Matters instead turned on intentions-on how one expected the other would use its armed forces. In the absence of reassuring information regarding Turkey's goals, Greece viewed superior Turkish military capacity as a real threat, and unequal alliance arms transfers were understandably troubling. When trust reigns, when one can safely assume that the other has benign motives for the foreseeable future, disparities in capabilities are hardly a menace.

81. Meinardus 1991, 161-63. See also Stephanou and Tsardanides 1991; Tsakaloyannis 1980; and Tsardanides 1988

82. Gonlubol $1975,48-49$.

83. Quoted in McCaskill 1988, 216. See also Papacosma 1984, 311; and Veremis 1988, 278. 
Although Turkish decision makers have proclaimed their country's status quo orientation, the combination of Greek presuppositions and rhetorical "noise" from Turkish domestic politics and the press have conspired to generate anxiety in the Greek camp. Turkish premier Bulent Ecevit's 1978 declaration that his country's national security is "primarily dependent on good relations and on establishing an atmosphere of mutual confidence with all our neighbors" was dismissed by Greeks as meaningless rhetoric, ${ }^{84}$ as they recalled Minister of Defense Ilchami Sancar's explicitly revisionist 1975 statement: "In the Aegean Sea the balance is obviously in Turkey's favor. This is true to such an extent that the eyes and thoughts of the Turks, former inhabitants of the islands, remain focused on islands a few miles from the Turkish coast, in hope of being able to reestablish themselves there one day." 85 The Greco-Turkish case points to the insufficiency of institutional transparency to generate cooperation, but it does not seem to support the stronger claim that the improved quantity and quality of information perceptibly harmed the rivals' relations. The contradictory statements of Turkish leaders would have reached Greece even in the absence of NATO, and the fevered rhetoric of the opposition was exposed through the increasingly democratic politics.

\section{Understanding Apparent Deviations}

The events of the 1950s seem to challenge the hypothesis regarding abandonment. Greece saw itself as a victim after the 1955 riots, and Dulles' identical letters to both parties were viewed by Greeks as a betrayal by the United States. This move should have resulted in greater Greek identification with alliance objectives and a renewed emphasis on the Soviet threat rather than regional interests. However, precisely the opposite occurred. The perceived abandonment led Greece to pursue a more independent foreign policy, although fear of the Soviet threat persisted, and Greece's attention to Turkey intensified. ${ }^{86}$ However, this apparent deviation from realist institutionalist expectations is just that. The events of 1955 corrected any Greek misimpression that NATO was interested in collective security rather than simply external deterrence, but Dulles' letters never undermined the security guarantee and, therefore, never threatened to leave either country to the Soviets. Instead of moderating Greek regional aims and smoothing any divergence between Greek goals and those of the alliance, this weaker form of abandonment exacerbated the conflict by indicating to Greece that the allies, and one important ally in particular, favored Turkey.

84. Ecevit 1984.

85. Quoted in Wilson 1984, 129. For a host of similar statements by Turkish leaders, see Platias 1991, 93; Couloumbis 1983, 131; and Papacosma 1984, 305.

86. On the growing divergence between Greek and U.S. policies, see, for example, Embassy in Greece to Department of State, 12 March 1956, FRUS 1955-1957, vol. 24, 347-48. OCB Report on Greece, 14 May 1958, FRUS 1958-1960, vol. 10, pt. 2, 617-18; OCB Report on Greece, 17 December 1958, FRUS 1958-1960, vol. 10, pt. 2, 645-46. For the persistence of Greek concerns regarding the Soviet threat, see Memorandum of Conversation, McGhee and Karamanlis, 29 January 1959, FRUS 1958-1960, vol. 10, pt. 2, 654; Memorandum of Conference, Eisenhower and Karamanlis, 15 December 1959, FRUS 1958-1960, vol. 10, pt. 2, 690. Interestingly, Greek fears of the Soviet Union begin to reappear in the documents only around 1959, when agreement with Turkey seemed imminent. 
A further puzzling finding is that, in the first two decades of the Cold War, even as the Turks vigorously pursued their regional interests, they did not describe Greece as a threat to national security. As one local analyst observes, "Many Turks continue to view the Greek question more as a nuisance than as a threat." 87 "The general attitude of the Turkish people towards the Greeks," comments another observer, "can better be characterized as indifference." 88 Where Greece was seen as an uncertain ally in declassified U.S. documents, Turkey was steadfast; where Greece was portrayed as often more concerned about its regional interests than those of the alliance, Turkey was depicted as a loyal ally; where Greek decision makers hinted, or occasionally explicitly identified, the Turkish threat, their Turkish counterparts were resolutely focused on the Soviet Union and its clients. ${ }^{89}$

Perhaps the documents reflect long-standing U.S. prejudices and thus reveal more about U.S. attitudes than about Greek and Turkish policymakers. Perhaps Turkey's leaders were more astute than Greece's leaders, recognizing that fear of an ally would garner less U.S. political, economic, and military support than the common struggle. Although both explanations may contain some truth, one can also account for this outcome from within the realist institutionalist framework. The Dulles letters, which implicitly held Turkey blameless, led Turkey to believe that it was more highly valued by the alliance than was its rival. The resultant sense of confidence reinforced the shift in foreign policy focus, translating into an unsurprising aggressiveness in the pursuit of regional aims. Even as U.S. diplomats praised Turkey's loyalty, they noted that it was highly "stubborn" on the Cyprus question, refusing to compromise in the tripartite negotiations of the late 1950s..$^{90}$ Moreover, given the two countries' roles in alliance plans and the corresponding pattern of assistance, the future of the regional distribution of military power seemed quite promising from a Turkish point of view. In short, Turkey believed that the political balance of power was tipped in its favor and that the military balance would soon follow suit. It had relatively little to fear from Greece, which was not likely to approach its allies to complain about aid disbursements. U.S. documents do, then, display a selection bias: Turkish leaders appeared resolutely focused on the Soviet threat because they had no other, and, satisfied with the U.S. tilt in their favor on regional questions, they had little else to discuss besides uncomfortable domestic issues that they preferred to avoid.

\section{Conclusion}

The Greco-Turkish case largely exhibits the dynamics highlighted by the propositions developed earlier. The structural realist dismissal of institutions as epiphenom-

87. Karaosmanoglu 1988, 317.

88. Kramer 1991, 59.

89. For examples of this tendency, see Rountree to MacArthur, 19 November 1956, FRUS 1955-1957, vol. 24, 702-704; Report on Turkey (NSC 5708/2), 29 January 1958, FRUS 1958-1960, vol. 10, pt. 2, 741-44; Statement of U.S. Policy Toward Turkey 5 October 1960, FRUS 1958-1960, vol. 10, pt. 2, 888-99.

90. Memorandum, Holmes to Dulles, 30 July 1956, FRUS 1955-1957, vol. 24, 391. 
enal to the distribution of power is not sustainable: institutions, including alliances, reshape states' definitions of their interests and pattern international interactions. Nor, however, is the unfailing optimism of neoliberal institutionalist theories justified, for membership in NATO proved destabilizing to the allies' relations. First, it externalized these small powers' security, encouraging a shift in foreign policy focus from the Soviet threat to regional interests, and prompting the emergence of the conflict at the zenith of the Cold War. Second, as Greece and Turkey engaged in contest over Cyprus, alliance arms transfers helped transform this limited dispute into a broader and deeper enmity. Third, in the context of this deteriorating relationship, those features of alliance theoretically conducive to cooperation failed to achieve that end. The transparency of capabilities fostered by the alliance could hardly calm decision makers anxious about the other's motives. The issue linkages it supplied did not aid the parties in negotiating a compromise, but rather helped to broaden the conflict as Greece and Turkey sought bargaining leverage. And even the alliance itself-its forums and its benefits-became an object of contest. International institutions are central to international relations, but they do not always foster cooperation, even among their members.

It is important to avoid several simplistic conclusions. I am not arguing that Greece and Turkey would not have clashed over Cyprus in the absence of membership in NATO. The contention between Greek and Turk is deeply rooted in history and geography, and had the two countries remained outside the alliance, their relations would no doubt have been punctuated by moments of discord. But neither would have risked exposing itself to Soviet attack in pursuit of its positive regional agenda. Nor am I suggesting that Greece and Turkey should have been excluded from NATO nearly half a century ago. A conclusion regarding the wisdom of that historical decision depends on estimates of the dispute's cost to the alliance, the states'contributions to coalition security, and the expected costs and benefits of other scenarios.

Finally, a realist institutionalist approach does not deny that certain aspects of alliances help moderate the rivalries within. First, NATO ensured that Greek and Turkish leaders met regularly. When such meetings were necessary to defuse tensions, yet politically impossible to arrange bilaterally, NATO usefully supplied a face-saving forum in which statesmen could move beyond rhetoric. Second, the alliance powerfully influenced the rivals indirectly, through the regular interaction of Greek and Turkish military officers, who gained greater understanding of their respective interests and perceptions. Third, their membership in the alliance provided the United States with a measure of influence over their behavior. Yet only under extraordinary circumstances did the United States summon the political will to force the pair to bend, and such moments were all too rare to stifle the conflict. However, despite the continual armed skirmishes and the virtually continuous war of words, the dispute never did erupt into full-fledged war, and for that NATO deserves some credit.

Advocates of NATO enlargement believe that the initiative will bring peace to East-Central Europe just as the alliance did to France and Germany. NATO, they assert, will prevent simmering tensions in the region from bubbling over, and perhaps in a limited sense it will. But alliances do not guarantee stability within their 
boundaries. Not only do they provoke balancing actions among the excluded; they can also arouse dangerous spirals of tension among members, creating "allied adversaries." The realist institutionalist propositions I have presented here seem to have relevance to East-Central Europe, where the seeds of future Greeces and Turkeys may already lie, awaiting the nurturing shelter of NATO membership. To assess this claim, I return to the original hypotheses and the stipulated necessary conditions.

That potential disputes are rife in the region is beyond contest, for otherwise the logic demanding NATO enlargement is truly absurd. Hungary's concerns about the treatment of its ethnic brethren in Romania, Slovakia, and Serbia are only the best known of a series of territorial and ethnic controversies. ${ }^{91}$ With NATO insisting that all prospective members settle their disputes with bordering states, Hungary and Romania signed a "friendship treaty" in 1996, but Greece and Turkey had concluded far deeper agreements before their problems resurfaced and had even considered forming a confederation. Hungarian and Romanian leaders have generally resisted nationalist pressures, but even if they continue to exhibit restraint-and that remains a big if, given their often contradictory behavior-local agitation will reduce their room for maneuver. Greek and Turkish Cypriots dragged their often reluctant ethnic compatriots into conflict, and nationalists in Transylvania have been trying to do the same.

Why do the states of East-Central Europe crave a place in the Atlantic alliance? No doubt the symbolism of joining the West in its moment of triumph is powerful. Moreover, Eastern European leaders often portray NATO as merely a stepping-stone to the EU, arguing that alliance membership will send a welcome signal to financial markets and investors. But they, of course, have every incentive to downplay fears of a resurgent Russia, since open admission of that motive would intensify Russian objections and strengthen the nationalist movement there. Leaders of the Visegrad states have been at best ambiguous in their public pronouncements. Even in the Czech Republic, according to a local pollster, the alliance represents safety from Russian expansionism: "It is highly confusing to the Czech people. They say, 'We want NATO against Russia, and if it's not against Russia, who needs it?"” To build support for joining the alliance, the government resorted to crude anti-Russian appeals, posting pictures of former Soviet leader Leonid Brezhnev above the sarcastic line: "Thank you for freely deciding not to join NATO." 92

Czech president Vaclav Havel has eloquently argued that NATO must include all "the West," all who embrace "Euro-American political and cultural values," but it is hardly a coincidence that he has explicitly excluded Russia from the ranks of possible members. Although Havel declared in 1997 that the alliance must transcend its Cold War origins, that Russia today poses little threat, just two years earlier he defended enlargement on a different basis: "because we do not know how the situation in Russia and the East is going to develop." ${ }^{93}$ Polish president Alexander Kwasniewski

91. Briefly reviewing a number of these is Carpenter 1994, 71-86.

92. New York Times, 10 February 1998, A21.

93. "NATO's Quality of Life," New York Times, 13 May 1997, A21; Deutsche Presse-Agentur, 18 January 1995 
has recently stressed NATO's advantages as "certainty, security, and guarantees," and Polish prime minister Jerzy Buzek has spoken of expansion as erasing "the shadow of Yalta." Hungarian leaders have generally emphasized that membership would signal their country's commitment to a market economy, but in February 1998 Foreign Minister Laszlo Kovacs warned that delaying enlargement "would send the wrong message, discourage reforms in the countries, and encourage extremists like Vladimir Zhirinovsky, who dreams of reestablishing control." Even as he declared that the former Warsaw Pact countries face no military threat at present, U.S. secretary of defense William Cohen justified admitting these nations into the alliance because of future security concerns, because they are situated between Russia and Germany and have historically suffered at the hands of one or the other. ${ }^{94}$

The combination of fear of Russian revanchism and the prevalence of secondorder disputes conspires to induce increased attention to conflicts of interest among longtime rivals in East-Central Europe. Not to worry, some maintain: the new NATO members will remain relatively weak. But such optimism may be misplaced. With the projected regional arms market amounting to some $\$ 35$ billion, U.S. weapons manufacturers were among the most aggressive pro-enlargement campaigners in Washington - the top six contractors spent $\$ 51$ million on lobbying over the last two years - and Lockheed-Martin's director of strategic planning headed the influential U.S. Committee to Expand NATO. U.S. diplomats and military officials have appeared at arms shows to plug U.S. products, and the Pentagon has even offered the Visegrad states giveaways of surplus weaponry and free five-year leases on advanced fighter aircraft. The United States has also created a host of loan and grant programs worth billions to prepare countries'militaries for NATO membership. Senator Tom Harkin has concluded that NATO expansion is "a Marshall Plan for defense contractors."

All three new entrants project rising military budgets in coming years, with Hungary leading the way, forecasting a 35 percent increase. Although initial procurements have involved communications and radar systems, there is little evidence that future military modernizations will remain equally modest. Poland plans to buy approximately 150 fighter planes, and Romania has already committed to purchasing nearly 100 Cobra attack helicopters.$^{95}$ And U.S. manufacturers are sure to press the U.S. government for further help in selling more such big-ticket items. Should EastCentral Europe become the new growth market for arms builders, thanks at least in part to generous aid programs, the consequences for regional stability would be disastrous.

This has been a very preliminary and cursory review of the situation in EastCentral Europe, and further research may demonstrate that the region can be expected to avoid the fate of Greece and Turkey - perhaps because most states in EastCentral Europe seek to join NATO not to protect themselves from a revival of Russian

94. See Associated Press, 3 May 1998; Agence France Press, 1 May 1998; Associated Press, 10 February 1998; and Associated Press, 21 October 1997.

95. See New York Times, 29 June 1997, A1; Nation, 21 July 1997, 24; European, 20 November 1997; Nation, 24 November 1997, 21; New York Times, 2 April 1998, A5; and Progressive, May 1998, 22. 
imperial ambitions, but to send a message to potential investors, or perhaps because larger allies will refuse to foot the bill to modernize Eastern European militaries and these states cannot afford new sophisticated armaments. But if these arguments are solid, policymakers have little foundation on which to rest the claim that enlargement will widen the "zone of peace." If Eastern European leaders realized that membership in the Atlantic alliance might produce divisive relations with their traditional rivals, they would not be so gung ho about tossing in their fortunes with NATO, and the current members might be more reluctant to swell their ranks. ${ }^{96}$

However, the analysis does suggest ways to minimize the destabilizing effect of enlargement. First, the widespread doubt that the United States would really risk New York (or even New Yorkers in the armed services) for Budapest or Prague or Warsaw may not be all to the bad. If Hungarians and Czechs and Poles do not fully trust NATO's security guarantee, membership in the alliance may not encourage them to focus on their regional interests. However, even when successful in the short run, the implicit threat of abandonment plays a dangerous game. Lyndon Johnson's carefully crafted note convinced Turkey not to invade in 1964, but the long-term impact on relations between Turkey and the alliance was adverse. Combined with other Turkish gripes, the letter motivated Ankara to look elsewhere for its security and welcome the normalization of relations with the Soviet bloc. George Ball's reaction to Johnson's letter was prescient: "I think that may stop Inönü from invading, but I don't know how we'll ever get him down off the ceiling after that." 97 The strategy of doubt may curb intra-alliance tensions but at the cost of the alliance itself.

Second, although NATO must require prospective allies to modernize their militaries and ensure interoperability with alliance forces, its current members should adopt strict standards to prevent the region from becoming the new hot spot for arms traders. Moreover, notwithstanding this article's skepticism regarding clear distinctions between offensive and defensive weaponry, NATO should assign the newest members primarily defensive roles, assist them in developing forces appropriate for those tasks, and discourage them from acquiring militaries capable of sustained offensive action. Finally, without undermining the coalition's capacity for action, NATO members should disburse military assistance in such a fashion as to equalize the rivals' capabilities. These policies will not fully assuage the concerns of regional rivalseven largely defensive force postures may still retain the capability to seize and hold a contested slice of territory-but they should mitigate the intra-alliance security dilemma. These tactics, too, are not without conceivable drawbacks. The stronger of the pair may, for example, recognize that the unequal assistance is closing its window of opportunity and may launch a preventive strike. Suspicious of its more powerful allies' motives, it may even fear that aid patterns portend a future window of vulnerability. Further, this approach toward assistance may, unless carefully managed, run

96. Relatedly, Jervis notes the possibility that "providing security guarantees to the countries of Eastern Europe might lead them to ... make fewer efforts to maintain good relations with their neighbors." Jervis 1997, 12.

97. Ball 1982, 350. See also Harris 1972 and 1975; and Bolukbasi 1993. 
counter to the alliance's priorities, restricting its flexibility, undermining its military effectiveness, and possibly destabilizing the larger strategic context.

Third, the current enlargement plan, which calls for admitting the Soviet Union's former satellites in staggered fashion, might aggravate the dynamics highlighted by the Greco-Turkish case. Between stages, the admitted rival would alone receive significant sums of military hardware and training as its forces were made compatible with alliance protocols. Staggered entrance may, therefore, create a set of unstable bilateral imbalances of power. Moreover, with its security assured, the newly admitted NATO member could devote greater attention to its regional agenda. Delaying a second round of admissions to the alliance may actually prove dangerous. If policymakers ignore these lessons of the past five decades, Greece and Turkey's past may become East-Central Europe's future, and NATO enlargement will then prove far more costly than anyone presently anticipates.

\section{References}

Acheson, Dean. 1969. Present at the Creation: My Years in the State Department. New York: W. W. Norton.

Alford, Jonathan, ed. 1984. Greece and Turkey: Adversity in Alliance. Aldershot, Hants: Gower.

Art, Robert. 1998. Creating a Disaster: NATO's Open Door Policy. Political Science Quarterly 113 (3): 383-403.

Asmus, Ronald D., Richard Kugler, and F. Stephen Larrabee. 1993. Building a New NATO: A New Transatlantic Bargain. Foreign Affairs 72 (4):28-40.

1995. NATO Expansion: The Next Steps. Survival 37 (1):7-33.

Bahcheli, Tozun. 1990. Greek-Turkish Relations Since 1955. Boulder, Colo.: Westview Press.

Baldwin, David A., ed. 1993. Neorealism and Neoliberalism: The Contemporary Debate. New York: Columbia University Press.

Ball, Christopher L. 1998. Nattering NATO Negativism? Reasons Why Expansion May Be a Good Thing. Review of International Studies 24 (1):43-67.

Ball, George W. 1982. The Past Has Another Pattern: Memoirs. New York: W. W. Norton.

Barham, Richard. 1982. Enosis: From Ethnic Communalism to Greek Nationalism in Cyprus, 1878-1955. Ph.D. diss., Columbia University.

Betts, Richard K. 1982. Surprise Attack: Lessons for Defense Planning. Washington, D.C.: The Brookings Institution.

- 1992. Systems for Peace or Causes of War: Collective Security, Arms Control, and the New Europe. International Security 17 (1):5-43.

Bolukbasi, Suha. 1993. The Johnson Letter Revisited. Middle Eastern Studies 29 (3):505-25.

Botsas, Eleftherios N. 1988. The U.S.-Cyprus-Turkey-Greece Tetragon: The Economics of an Alliance. Journal of Political and Military Sociology 16 (2):247-62.

Brown, James. 1991. Delicately Poised Allies, Greece and Turkey: Problems, Policy Choices, and Mediterranean Security. London: Brassey's.

Brown, Michael. 1995. The Flawed Logic of NATO Expansion. Survival 37 (1):34-52.

Bueno de Mesquita, Bruce. 1981. The War Trap. New Haven, Conn.: Yale University Press.

Camp, Glen D. 1980. Greek-Turkish Conflict over Cyprus. Political Science Quarterly 95 (1):43-70.

Carpenter, Ted Galen. 1994. Beyond NATO: Staying Out of Europe's Wars. Washington, D.C.: CATO Institute.

Chernoff, Fred. 1995. After Bipolarity: The Vanishing Threat, Theories of Cooperation, and the Future of the Atlantic Alliance. Ann Arbor: University of Michigan Press. 
Clogg, Richard. 1991. Greek-Turkish Relations in the Post-1974 Period. In The Greek-Turkish Conflict in the 1990s: Domestic and External Influences, edited by Dimitri Constas, 12-26. London: Macmillan.

Constas, Dimitri, ed. 1991. The Greek-Turkish Conflict in the 1990s: Domestic and External Influences. London: Macmillan.

Coufoudakis, Van. 1985. Greek-Turkish Relations, 1973-1983: The View from Athens. International Security 9 (4):185-217.

. 1991. Greek Political Party Attitudes Towards Turkey: 1974-1989. In The Greek-Turkish Conflict in the 1990s: Domestic and External Influences, edited by Dimitri Constas, 40-56. London: Macmillan.

Couloumbis, Theodore. 1983. The United States, Greece, and Turkey: The Troubled Triangle. New York: Praeger.

Duffield, John S. 1994. NATO's Functions After the Cold War. Political Science Quarterly 109 (5): 763-87.

- 1995. Power Rules: The Evolution of NATO's Conventional Force Posture. Stanford, Calif: Stanford University Press.

Ecevit, Bulent. 1984. Turkey's Security Policies. In Greece and Turkey: Adversity in Alliance, edited by Jonathan Alford, 136-41. Aldershot: Gower.

Eckstein, Harry. 1975. Case Study and Theory in Political Science. In Strategies of Inquiry: Handbook of Political Science. Vol. 7, edited by Fred I. Greenstein and Nelson W. Polsby, 79-137. Reading, Mass.: Addison-Wesley.

Evangelista, Matthew. 1991. Greece, Turkey, and the Improvement of U.S.-Soviet Relations. In The Greek-Turkish Conflict in the 1990s: Domestic and External Influences, edited by Dimitri Constas, 142-48. London: Macmillan.

Glaser, Charles. 1997. The Security Dilemma Revisited. World Politics 50 (1):171-201.

Glaser, Charles, and Chaim Kaufmann. 1998. What Is the Offense-Defense Balance and How Can We Measure It? International Security 22 (4):44-82.

Gonlubol, Mehmet. 1975. NATO, USA, and Turkey. In Turkey's Foreign Policy in Transition, 1950-1974, edited by Kemal H. Karpat, 13-50. Leiden: E. J. Brill.

Gowa, Joanne. 1989. Rational Hegemons, Excludable Goods, and Small Groups: An Epitaph for Hegemonic Stability Theory? World Politics 41 (3):307-24.

Grieco, Joseph. 1993. Understanding the Problem of International Cooperation. In Neorealism and Neoliberalism, edited by David Baldwin, 301-38. New York: Columbia University Press.

Haas, Peter M. 1990. Saving the Mediterranean: The Politics of International Environmental Cooperation. New York: Columbia University Press.

Haas, Peter M., ed. 1992. Knowledge, Power, and International Policy-Coordination. International Organization 46 (1). Special issue.

Haass, Richard. 1988. Alliance Problems in the Eastern Mediterranean—Greece, Turkey, and Cyprus: Part I. In Prospects for Security in the Mediterranean, edited by Robert O'Neill, 61-71. London: Macmillan.

Harris, George S. 1972. Troubled Alliance: Turkish-American Problems in Historical Perspective, 1945 1971. Washington, D.C.: American Enterprise Institute.

. 1975. Turkey and the United States. In Turkey's Foreign Policy in Transition, 1950-1974, edited by Kemal H. Karpat, 51-72. Leiden: E. J. Brill.

Hatzivassiliou, Evanthis. 1995. Security and the European Option: Greek Foreign Policy, 1952-62. Journal of Contemporary History 30 (1):187-202.

Hellmann, Gunther, and Reinhard Wolf. 1993. Neorealism, Neoliberal Institutionalism, and the Future of NATO. Security Studies 3 (autumn):3-43.

Holsti, Ole R., P. Terrence Hoppman, and John D. Sullivan. 1973. Unity and Disintegration in International Alliances: Cooperative Studies. New York: Wiley.

Jervis, Robert. 1976. Perception and Misperception in International Politics. Princeton, N.J.: Princeton University Press.

. 1978. Cooperation Under the Security Dilemma. World Politics 30 (2):167-214. 
1983. Security Regimes. In International Regimes, edited by Stephen Krasner, 173-94. Ithaca, N.Y.: Cornell University Press.

1997. System Effects. Princeton, N.J.: Princeton University Press.

Karaosmanoglu, Ali. 1988. Turkey and the Southern Flank: Domestic and External Contexts. In NATO's Southern Allies: Internal and External Challenges, edited by John Chipman, 287-353. London: Routledge.

Keohane, Robert O. 1984. After Hegemony: Cooperation and Discord in the World Political Economy. Princeton, N.J.: Princeton University Press.

- 1988. Alliances, Threats, and the Uses of Neorealism. International Security 13 (1):169-76.

1989. International Institutions and State Power: Essays in International Relations Theory. Boulder, Colo.: Westview Press.

1993. Institutional Theory and the Realist Challenge After the Cold War. In Neorealism and Neoliberalism, edited by David Baldwin, 269-300. New York: Columbia University Press.

Keohane, Robert O., and Lisa L. Martin. 1995. The Promise of Institutionalist Theory. International Security 20 (1):39-51.

Kramer, Heinz. 1991. Turkey's Relations with Greece. In The Greek-Turkish Conflict in the 1990s: Domestic and External Influences, edited by Dimitri Constas, 57-72. London: Macmillan.

Kupchan, Charles A. 1988. NATO and the Persian Gulf: Examining Intra-Alliance Behavior. International Organization 42 (2):317-46.

Kurop, Marcia. 1998. Greece and Turkey: Can They Mend Fences? Foreign Affairs 77 (1):7-12.

Lee, Steven Hugh. 1995. Outposts of Empire: Korea, Vietnam, and the Origins of the Cold War in Asia, 1949-1954. Montreal: McGill-Queen's University Press.

Leffler, Melvyn P. 1992. A Preponderance of Power: National Security, the Truman Administration, and the Cold War. Stanford, Calif.: Stanford University Press.

Levy, Jack. 1984. The Offensive/Defensive Balance of Military Technology: A Theoretical and Historical Analysis. International Studies Quarterly 28 (2):219-38.

- 1989. The Causes of War. In Behavior, Society, and Nuclear War. Vol. I, edited by Philip E. Tetlock, Jo Husbands, Robert Jervis, Paul Stern, and Charles Tilly, 209-333. New York: Oxford University Press.

Lijphart, Arend. 1971. Comparative Politics and the Comparative Method. American Political Science Review 65 (3):682-93.

Lipson, Charles. 1984. International Cooperation in Economic and Security Affairs. World Politics 37 (1):1-23.

Lynn-Jones, Sean. 1995. Offense-Defense Theory and Its Critics. Security Studies 4 (summer):660-91.

Mandelbaum, Michael. 1996. The Dawn of Peace in Europe. New York: The Twentieth Century Fund Press.

Mansfield, Edward. 1995. International Institutions and Economic Sanctions. World Politics 47 (4):575605.

Martin, Lisa L., and Beth A. Simmons. 1998. Theories and Empirical Studies of International Institutions. International Organization 52 (4):729-57.

McCalla, Robert B. 1996. NATO's Persistence After the Cold War. International Organization 50 (3): 445-75.

McCaskill, Charles W. 1988. U.S.-Greek Relations and the Problems of the Aegean and Cyprus. Journal of Political and Military Sociology 16 (2):215-33.

McDonald, Robert. 1988. Alliance Problems in the Eastern Mediterranean—Greece, Turkey, and Cyprus: Part II. In Prospects for Security in the Mediterranean, edited by Robert O'Neill, 72-89. London: Macmillan.

Mearsheimer, John J. 1983. Conventional Deterrence. Ithaca, N.Y.: Cornell University Press.

. 1990. Back to the Future: Instability in Europe After the Cold War. International Security 15 (1):5-56.

. 1994. The False Promise of International Institutions. International Security 19 (3):5-49. 
Meinardus, Ronald. 1991. Third-Party Involvement in Greek-Turkish Disputes. In The Greek-Turkish Conflict in the 1990s: Domestic and External Influences, edited by Dimitri Constas, 157-63. London: Macmillan.

Mercer, Jonathan. 1996. Reputation and International Politics. Ithaca, N.Y.: Cornell University Press.

Milner, Helen. 1992. International Theories of Cooperation Among Nations: Strengths and Weaknesses. World Politics 44 (3):466-96.

Morgenthau, Hans J. [1948] 1993. Politics Among Nations: The Struggle for Power and Peace. Brief ed. Revised by Kenneth W. Thompson. New York: McGraw Hill.

Olson, Mancur, Jr., and Richard Zeckhauser. 1966. An Economic Theory of Alliances. Review of Economics and Statistics 48:266-79.

Oye, Kenneth A., ed. 1986. Cooperation Under Anarchy. Princeton, N.J.: Princeton University Press.

Papacosma, S. Victor. 1984. Legacy of Strife: Greece, Turkey, and the Aegean. Studia Diplomatica 37 (3):295-318.

Perlmutter, Amos, and Ted Galen Carpenter. 1998. NATO’s Expensive Trip East: The Folly of Enlargement. Foreign Affairs 77 (1):2-6.

Platias, Athanasios. 1991. Greece's Strategic Doctrine. In The Greek-Turkish Conflict in the 1990s: Domestic and External Influences, edited by Dimitri Constas, 91-108. London: Macmillan.

Psomiades, Harry J. 1968. The Eastern Question: The Last Phase. Salonica: Institute for Balkan Studies.

Ray, James Lee. 1990. Friends as Foes: International Conflict and Wars Between Formal Allies. In Prisoners of War?: Nation-States in the Modern Era, edited by Charles S. Gochman and Alan Ned Sabrosky, 73-91. Lexington, Mass.: Lexington Books.

Risse-Kappen, Thomas. 1995. Cooperation Among Democracies: The European Influence on U.S. Foreign Policy. Princeton, N.J.: Princeton University Press.

Roubatis, Yiannis. 1979. The United States and the Operational Responsibilities of the Greek Armed Forces, 1947-1977. Journal of the Hellenic Diaspora 6 (spring):39-57.

Russett, Bruce, and Allan C. Stam. 1998. Courting Disaster: An Expanded NATO Versus Russia and China. Political Science Quarterly 113 (3):361-82.

Schroeder, Paul W. 1976. Alliances, 1815-1945: Weapons of Power and Tools of Management. In Historical Dimensions of National Security Problems, edited by Klaus Knorr, 227-62. Lawrence: University Press of Kansas.

1994. Historical Reality Versus Neo-realist Theory. International Security 19 (1):108-48.

Schweller, Randall L. 1994. Bandwagoning for Profit: Bringing the Revisionist State Back In. International Security 19 (1):72-107.

Schweller, Randall L., and David Priess. 1997. A Tale of Two Realisms: Expanding the Institutions Debate. Mershon International Studies Review 41 (spring):1-32.

Sebenius, James K. 1983. Negotiation Arithmetic: Adding and Subtracting Issues and Parties. International Organization 37 (2):281-316.

Shimshoni, Jonathan. 1990. Technology, Military Advantage, and World War I: A Case for Military Entrepreneurship. International Security 15 (3):187-215.

Snidal, Duncan. 1991. International Cooperation Among Relative Gains Maximizers. International Studies Quarterly 35 (4):387-402.

Snyder, Glenn H. 1997. Alliance Politics. Ithaca, N.Y.: Cornell University Press.

Snyder, Jack. 1990. Averting Anarchy in the New Europe. International Security 14 (4):5-41.

Stearns, Monteagle. 1992. Entangled Allies: U.S. Policy Toward Greece, Turkey, and Cyprus. New York: Council on Foreign Relations Press.

Stein, Arthur A. 1990. Why Nations Cooperate: Circumstance and Choice in International Relations. Ithaca, N.Y.: Cornell University Press.

Stephanou, Constantine, and Charalambos Tsardanides. 1991. The EC Factor in the Greek-Turkey-Cyprus Triangle. In The Greek-Turkish Conflict in the 1990s: Domestic and External Influences, edited by Dimitri Constas, 207-30. London: Macmillan.

Tsakaloyannis, Panos. 1980. The European Community and the Greek-Turkish Dispute. Journal of Common Market Studies 19 (1):35-54. 
Tsardanidis, Charalambos. 1988. The European Community and the Cyprus Problem Since 1974. Journal of Political and Military Sociology 16 (fall):155-71.

U.S. Department of State. 1989. Foreign Relations of the United States: 1955-1957, vol. 24. Washington, D.C.: U.S. Government Printing Office.

. 1993. Foreign Relations of the United States: 1958-1960, vol. 10, pt. 2. Washington D.C.: U.S. Government Printing Office.

Van Evera, Stephen. 1998. Offense, Defense, and the Causes of War. International Security 22 (4):5-43.

Veremis, Thanos. 1984. Greek Security: Issues and Politics. In Greece and Turkey: Adversity in Alliance, edited by Jonathan Alford, 1-42. Aldershot: Gower.

. 1988. Greece and NATO: Continuity and Change. In NATO's Southern Allies, edited by John Chipman, 236-86. London: Routledge.

Wallander, Celeste, and Robert Keohane. 1998. Risk, Threat, and Security Institutions. Unpublished manuscript, Harvard University and Duke University.

Walt, Stephen M. 1987. The Origins of Alliances. Ithaca, N.Y.: Cornell University Press.

. 1997. Why Alliances Endure or Collapse. Survival 39 (spring):156-79.

Waltz, Kenneth N. 1979. Theory of International Politics. New York: McGraw-Hill.

1993. The Emerging Structure of International Politics. International Security 18 (2):44-79.

Weber, Steve. 1992. Shaping the Postwar Balance of Power: Multilateralism in NATO. International Organization 46 (3):633-80.

Weitsman, Patricia. 1997. Intimate Enemies: The Politics of Peacetime Alliance. Security Studies 7 (autumn): $156-92$.

Wilson, Andrew. 1984. The Aegean Dispute. In Greece and Turkey: Adversity in Alliance, edited by Jonathan Alford, 90-130. Aldershot: Gower.

Xydis, Stephen G. 1967. Cyprus: Conflict and Conciliation, 1954-1958. Columbus: Ohio State University Press. 